\title{
Microplastics in Aquatic Environments: Sources, Ecotoxicity, Detection \& Remediation
}

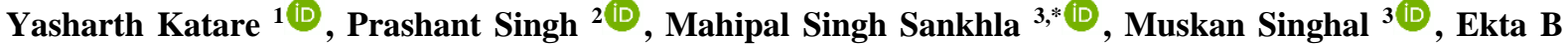 \\ Jadhav $^{4(D)}$, Kapil Parihar ${ }^{5(D)}$, Bhagyashri T. Nikalje ${ }^{6}$ (D) , Ashutosh Trpathi ${ }^{1}$ (D) , Leena Bhardwaj ${ }^{7}$ (D) \\ 1 Institute of Sciences, SAGE University, Indore, M.P., India; yasharth4n6@gmail.com (Y.K.); \\ hodscience@sageuniversity.in (A.T); \\ 2 School of Forensic Science, National Forensic Science University, Gandhinagar, Gujrat, India; singhp1103@gmail.com \\ (P.S.); \\ 3 Department of Forensic Science, Vivekanand Global University, Jaipur, Rajasthan, India; mahipal4n6@gmail.com \\ (M.S.S.); muskansinghal2013@gmail.com (M.S.); \\ 4 Government Institute of Forensic Science, Aurangabad, Maharashtra, India; ekta.4n6@ gmail.com (E.B.J.); \\ 5 State Forensic Science Laboratory, Jaipur, Rajasthan, India; kparihar94@ gmail.com (K.P.); \\ 6 School of Doctoral Studies and Research, National Forensic Science University, Gandhinagar, Gujrat, India; \\ bhagyashri25nikalje@gmail.com (B.T.N.); \\ 7 Institute of Higher Education \& Research Centre, Delhi, India; leena.bhardwaj2000@gmail.com (L.B.); \\ * Correspondence: mahipal4n6@gmail.com (M.S.S.);
}

Scopus Author ID 57219964786

Received: 20.06.2021; Revised: 28.07.2021; Accepted: 1.08.2021; Published: 8.08.2021

\begin{abstract}
Microplastic pollutants are increasingly posing a significant threat of aquatic contamination and causing various adverse effects on the aquatic environment as well as human health. Microplastics are hazardous chemicals to marine and freshwater ecosystems; therefore, it is becoming a severe concern for ecology. Microplastics can also expose via drinking water and can be vulnerable to all living organisms. Microplastics work as carriers for various toxic components such as additives and other hazardous substances from industrial and urbanized areas. These microplastic contaminated effluents are ultimately transferred into water systems and directly ingested by organisms associated with a particular ecosystem. The microplastics components also pose an indirect threat to aquatic ecosystems by adsorbing surrounding other water pollutants. Due to the luxuriant discharge of billion tons of plastic waste from domestic to industrial level every year, degraded microplastics get accumulated in various aquatic systems, contaminate, and introduce into the food chain. This review mainly focuses on occurrence, factors influencing the release of microplastics into aquatic ecosystems, possible impact of these toxic micro-sized particles on human health and aquatic life. This study also briefly discusses removing microplastics from effluent and water systems using different advanced final-stage treatment technologies.
\end{abstract}

Keywords: plastic; pollutants; water; toxicity; microplastics; nanoplastics.

(c) 2021 by the authors. This article is an open-access article distributed under the terms and conditions of the Creative Commons Attribution (CC BY) license (https://creativecommons.org/licenses/by/4.0/).

\section{Introduction}

Global plastic production has led to the contamination of the environment (especially the water environments, contributing to excess water pollution), increasing a threat to society. Due to the increase in total manufacturing of plastics, microplastics have become a serious aquatic problem. It is necessary to understand; microplastic's prospective sources and sinks; it is the process by which distribution is affected; and their uptake and exchange in ecosystems; for understanding potential and ecological harm done by microplastics [1]. Depending on how 
they are produced, microplastics are divided into two parts primary and secondary. Primary microplastics are minute plastic pieces that are free directly or indirectly in the surrounding microplastics that can be released directly by the spills, sewage, and domestic and industrial effluent, whereas microplastic'indirect release took place via an overspill. The array of main microplastic particles, i.e., primary microplastic, includes wreckage [2]. There are several ways by which microplastics can come into freshwater surroundings: majorly as of the float up surfeit and waste material waste matter, however conjointly from mutual drain overflows, degraded plastic waste from industrial effluent, and part authentication. Though, there square measure insufficient information to inform the precise involvement of the variety of input. Additionally, several items of proof relating to similar shows that some microplastics that square measure found in drinkable might return from the dealing and supply systems of water and/or bottling of drinking water. A fresh regular assessment of the journalism was done, which identifies the 50 studies on the recognition of microplastics in freshwater, drinking water, and wastewater [3]. Microplastics are termed plastic particles that are less than $5 \mathrm{~mm}$ in dimensions. Primary Microplastic is mainly used in coarse clear-out carriers and artificial powder used for molding. Therefore microplastic is intentionally produced in minute sizes like virgin resin pellets. Whereas secondary microplastics square, measure the results of fragmentation of larger plastic particles. Crumbling will happen throughout the employment of many resources like textiles, smears, and tires, or once the plastics are discharged into the atmosphere. Each primary and secondary microplastic square measure is found within the atmosphere [4]. With an entire world's production of $335 \mathrm{M}$ tons in 2016, the rate of plastic production increased, due to which the total quantity of microplastic in the marine system continues to rise. There area unit many characteristics like corrosion resistance, like within the building of medication. The plastics might incorporate extra chemicals throughout production to administer distinctive and specific characteristics to the plastic. However, it can flip unhealthful if taken in by the body. Chemicals present in the environment can also be absorbed or incorporated by the plastics present in the environment [5-9]. Both benthic and pelagic fish may swallow microplastic directly or indirectly (i.e., directly by the water or indirectly via a prey). Microplastics can also be ingested by the birds and mammals that feed on aquatic organisms or lives in the aquatic environment [10-14]. Ecotoxicological microplastic studies have been conducted primarily on marine (77\%) and freshwater (23\%) organisms. Many researchers worked on the behavior of microplastic in the aquatic environment. Terrestrial runoff directly affects freshwater organisms [15-18]. A total of a hundred thirty studies reportage ecotoxicological effects of microplastic on marine environment was known Crustaceans, which were the foremost unremarkably calculated biological group (45\%), followed by fish (21\%), mollusks (18\%), annelid worms (7\%), echinoderms $(7 \%)$ and rotifers (2\%). This organism occupies different positions in different aquatic food webs. Fish can be top or intermediate predators as they can either intake microplastic directly or through indirect consumption, i.e., through grasses [19-22]. Little crustaceans are typically primary consumers, as are being rotifers [23]. Mollusks embrace a variety of economically and commercially necessary filter-feeding species. Due to their environment and eating behavior, mollusks and alternative benthonic organism teams like annelid worms can be littered with microplastic. The major sources of microplastics accumulations in aquatic environments are depicted in Figure 1. 


\section{Sources of MP Contamination in Aquatic Environments}

\subsection{Primary sources.}

Altered nano-sized plastics, mainly known as primary microplastics, are introduced directly into the aquatic environment, by discharging directly later than using them or by the fortuitous spills.

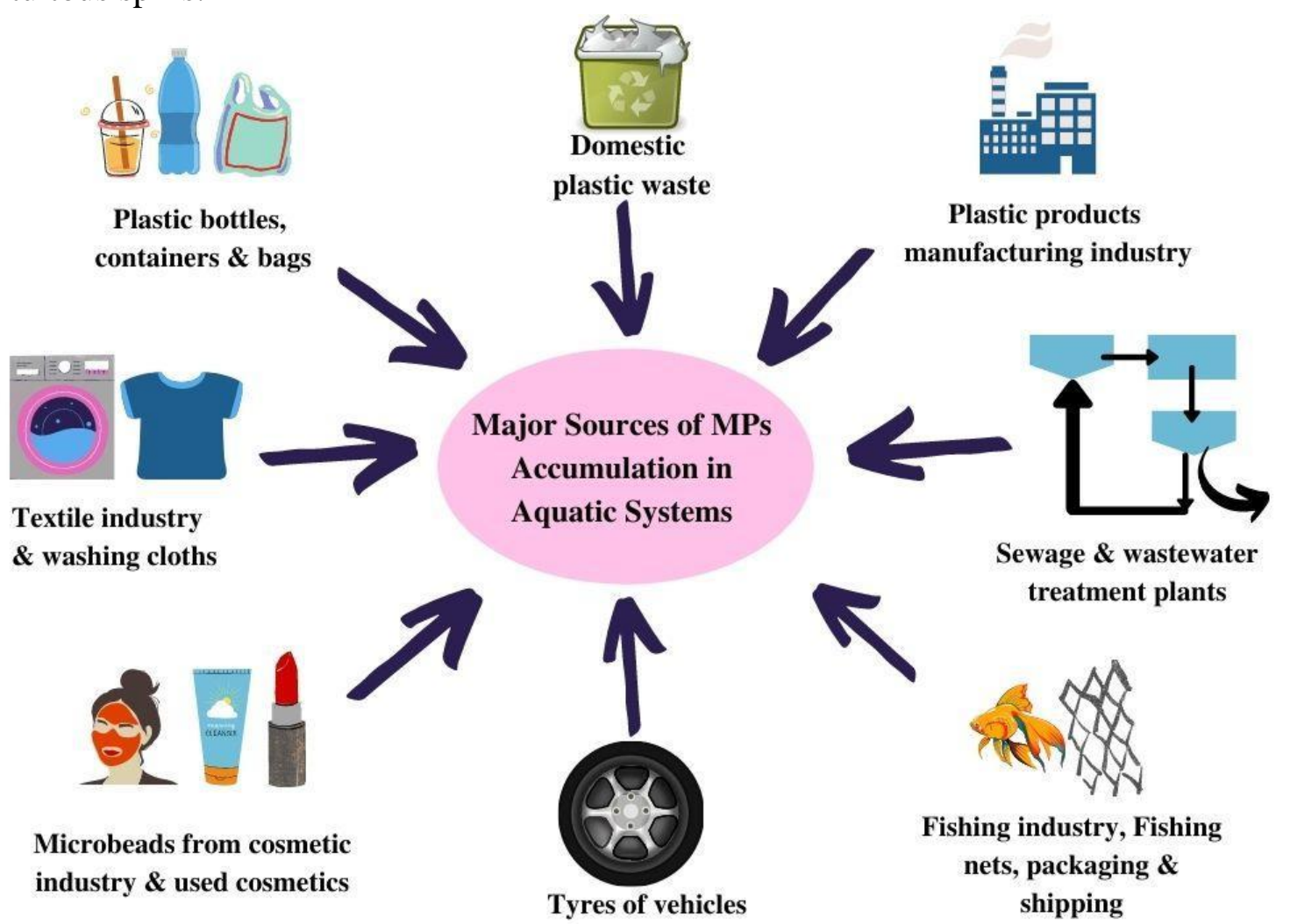

Figure 1. Major sources of microplastics in aquatic systems.

The process can make secondary microplastic of fermentation. In 2014 global microplastic production increased drastically. It reached two hundred ninety-nine million tons [24]. A calculable 4.8-12.7 million plenty of plastic material enters the water body from ground source in 192 coastal countries in 2010 [25]. If ocean-based sources, like shipping activities, square measure enclosed, the full effort of plastics to the aquatic bodies is significantly more. One calculates approximately for the least amount of plastic litter floating on the surface $(0.33$ millimeter in dimension) within the bushel is 0.27 tons (5.25 trillion particles), with microplastics (0.33-4.75 millimeter in size) accounting for ninety-two you curious about the range of plastic particles and thirteen you curious about weight [26]. However, this knowledge does not embody plastics on the bottom [27] and beaches [28] or those of particle size zero.001-0.33 mm, which accounts for the bulk of the whole loads of plastic-based contaminants [29]. Microplastics area unit experiential on the coast, the surface of the ocean, and bed from the seashore to the untie deep-sea, as well as the frozen [30] and Antarctic Oceans [31]. Those microplastics area units have been taken in by varied biotas, like invertebrates, turtles, fishes, birds, and marine mammals [32], and some ten you look after the information of encounter linking aquatic debris and genus currently relay to encounter with microplastic scrap [33]. After intake, microplastics may end up in undesirable physical [34, 32] and chemical $[35,36]$ sound effects on these microorganisms because of their variant range and connected 
toxicants [37,38], and the safety of seafood is also of great concern to environmentalists [39]. In inferior sewage, once the CAS method is finished, the amount of primary and secondary effluent is estimated. The first MPs comprised $19 \%$ and secondary Microplastic $81 \%$ of the total quantity of microplastic. After the last-stage management, the equivalent figures were ninety-one in the last effluent. The primary microplastic comprises microbeads from delicate care products, and resultant microplastic comprises artificial fabric fiber and uneven pieces of plastics. With the purification level amount of secondary microplastic also increased. More secondary microplastic than the primary microplastic is probably synthetic because their minute size and features can easily pass through the minute opening. The proportions of both the kind of microplastic in effluent samples were also expected. Characterizing microplastic into primary and secondary particles is a useful feature as it helped find their source and identify the ways to minimize their participation in the environmental surrounding [41]. By the visual inspection of the microplastic, their sources can be estimated depending upon the difference in shape and size. For example, both private and public sectors had issued guidelines not to use microplastics in microbeads and personal care products [42]. Also, companies have developed filters that help remove artificial fibers from washing machine wastewater [43]. However, notwithstanding a part of the microplastic getting into WWTPs might be distant with solutions based on the source, there will still be a big percentage of unrecognizable primary and secondary microplastic, which can stay the priority of WWTPs.

\subsubsection{Household and municipal sewage.}

Researchers have washed clothes in the household washing machine in the laboratory and noticed a large amount of fiber like microplastic in the drainage of the washing machine [44], they also concluded that the use of detergent increased the level of microplastics in the drainage [45]. Therefore, various sources are causative to microplastic contamination of the freshwater environment. Sewage management projects are considered the direct cause of microplastic contamination $[46,47]$ and earthly contribution from mud wearing away or plane surplus [48]. The contribution of these sources remains contentious. Scientists [49] found that just about no plastics pieces were found within a tertiary waste matter treatment plant release in Southern Golden State. The amount of plastics contaminants within the secondary waste the matter treatment plant's effluent was also low (with a median of just one microplastic particle per 1.14 liters of sewage). In distinction, most microplastics were initiated within the chief management phase [50].

\subsubsection{Industrial effluents.}

Artificial textiles, delicate heed products, industrial raw materials are the major sources of plastic contaminants that are brought into being in freshwater surroundings, and the reason is inappropriate dumping of artificial contaminants. Microplastic contamination is a universal issue and is a matter of great concern. And it is important to estimate the concentration of microplastic. For example, $3.5 \times 10^{3}$ microplastic units $\cdot \mathrm{L}-1$ were found within the water residue inside the U.S.A., and as small in concert $2 \times 10^{-4}$ units $\cdot \mathrm{L}-1$ in countries with a skinny population like Mongolia. The foremost compound constituent of plastics initiates in freshwaters area unit referred to as polymer (PE), plastic (PP), phenylethylene (PS), and artificial organic compound terephthalate (PET), accounting for seventieth of the total, each with associate degree alike occurrence of prevalence [51]. 


\subsection{Secondary sources.}

In 2015 the global thermoplastic production reached 322 million tonnes [52]. The different kinds of polymers created have distinctive characteristics when put next to ancient materials, especially in expressions of sturdiness, manufacturing prices, mass, potency, elasticity, and restricted electrical, physical phenomenon. Due to this, plastic products were used more and more in several areas like constructing sites, transporting, family merchandise, and wrapping. Now adays, four main plastics dominate thermoplastic: polyethylene, polyethylene terephthalate, polypropylene, and polyvinyl chloride [53]. Rubber is produced in tons in the market. The market mainly sells two main classes of rubber viz. natural rubber and synthetic rubber [54]. As an effect of the increasing making of plastics, their extensive use, and the misdirection of devastation, the number of plastics within the surroundings is mounting fast.

\section{MPs Vulnerable Water Bodies}

It is estimated that approximately $10 \%$ of total plastic produced is released into the oceans [56]. Furthermore, it is estimated that $33 \%$ of plastic is manufactured so that it can be re-used every year, which is redundant within 12 months [57] from the whole urban waste produced globally, $16 \%$ is only of plastic waste [58]. Predictably, a lot of plastic that is found or used on the land is discarded into the water bodies. It is estimated that nearly $15-50 \%$ of plastic waste alone is dumped in oceans [62]. It usually happens once land-filled or unnecessary plastic square measures are based on conclusions carried by airflow or goes into different water bodies like oceans, rivers, lakes, and many more. Associate in nursing evaluation by the international organization Joint cluster of specialists' allover this eightieth of pollutant within the aquatic surroundings comes from land. Whereas solely two-hundredth are, the result of activities stumped [63]. Moreover, it has' been calculable that in 2010 approximately 4.813.7 million tons of desecrating enter the deep-sea alone, [59] whereas approximately in 2015 about 9 million tons were calculable to possess been free [60]. By 2050 this quantity is anticipated to extend to around 32 million tons each year [61]. It has been calculable that ninetieth of all floating dust hanging on the plane of the marine surroundings consists of the plastic and their square measure over five trillion items deliberation nearly 269,000 tones [62].

\subsection{Freshwater ecosystem and drinking water.}

The freshwater ecosystem is the primary source of plastic contaminants, as they receive microplastics from the terrestrial surroundings and transport the contaminated water o the marine surroundings $[64,65]$. Moreover, rivers, streams, ditches, lakes, and ponds come under freshwater sources, which vary in size, location, habitat, and many more. There are many ways by which larger plastic stuff or scrap will enter the fresh surroundings, which are given in [64, 65]. Rural plastics or sewage-sludge-derived fibers and microbeads area unit the results of agricultural emptying and runoff from farmland. Storm emptying and concrete runoff area units are usually unfiltered and unprocessed and might include microplastics from tarnished path coats and show-off from vehicles [64, 65]. Microplastic wastewater treatment plants are used to minimize the plastic pollutant but, what are their initial inputs have plastic contain [66]. Combined sewerage overflows (CSOs) area unit was made to unleash untreated sewerage into encompassing water bodies to cut back the pressure point on emptying water system, cathartic each micro-plastic and macro-plastic pollutant. Researcher's counsels that the though points 
were contamination is maximum might took place in shut closeness to civilized areas, the bulk of plastics contaminated area unit possible to go into water bodies because of emptying systems and therefore thought should even be made on the input together with sewage overflows, [62, 67] though freshwater microplastic studies mainly concentrate on water bodies. Therefore, microplastics are also present within several freshwater systems [68-70] within the same suggests that as rivers [71]. It was studied that $75 \%$ of plastics contaminate at hand in the sediments of Lake Ontario, Canada, but in the center of the lake, there was no plastic contamination in the radius of $8 \mathrm{~cm}$ [62]. Based on studies, the researchers concluded that around 1977, microplastic gets to accumulate in the water body [78]. Polyethylene was found in maximum quantity, i.e., nearly $74 \%$ of the plastics waste contains polythene, then supported by $17 \%$ polypropylene and then $9 \%$ nitrocellulose and between $0.5 \mathrm{~mm}$ to $3.5 \mathrm{~mm}$ dimension [62]. Natural flowing water resources can help transport plastic pollutants out of those freshwater resources into marine water resources like rivers and estuaries. The body of water setting may be distinctive and productive marine environs as an outcome of their changeable salinity [72]. Because of tidal changes, air flows in and out in Estuaries [73]. This is unstable here; due to the tidal changes, water currents flow both in and out. Due to these environmental surroundings can result in the accumulation of colloidal Microplastics, standardization, and spatial distribution [74] suspensions of particles that fall out hooked on a bigger bunch that later on sinks to the lowest and pollutant sediment [75]. An investigation [76] establishes the speed of gathering prime microplastics, within the type of pellet from engineering sources was captivated with the number of precipitation therein region [62]. Thus, the excess precipitation phase results in bigger pellet authentication on the borderline of the source [78]. The researchers endorsed this to accrued water flows through tributaries that feed into the lake and thus, transport the pellets there. Within the St Lawrence stream in Québec, Canada, a study [77] of the stream sediments found that the typical density of $0.4 \mathrm{~mm}-2.16 \mathrm{~mm}$ synthetic resin microbead was one of the ten sites sampled on the stream had several microplastics [62].

\subsection{Marine water ecosystem and coastal zone.}

The existence and quantity of plastic contaminant in the water bodies has been broadly studied. It is considered that all the plastic gets accumulated in the oceans; therefore, there are many ways through which microplastic can enter the aquatic system $[65,78]$. Unintentional merchandise loss and black-market selling are some ways by which fishes can directly enter oceans [77]. Macroplastic waste degrades to form microplastic in the environment [77]. Microplastics are found at various places in an aquatic environment but accumulate at a specific location. For example, marine waves lead to particular areas where contaminants get to gather, such as the 'Great Pacific Garbage Patch' [79]. For the process of transportation of plastic contaminants from the oceans, special strategies have been [28-30] told about the transportation process of microplastic waste from marine water to freshwater [77, 80]. According to research [81], the production of polystyrene began in 1930. In the early 1970s, polystyrene microplastics began to be noticed, ranging from transparent clear to creamy white, a diameter of $0.2 \mathrm{~mm}-2.5 \mathrm{~mm}$, on the water surface of the Atlantic Ocean in the North [82,83]. This start resulted from polystyrene microplastic as the most frequently occurring microplastic in the environment. Some researchers [84] took the sample of the surface water of the North Pacific Gyre and found that was the main component of the collected sample. Polyamide (nylon) acts as a monomer of the fishing line [85]. A severe increase in the number of plastic contaminants into the water bodies was noticed [86]. The study [84] from 2001 concerned with taking 
samples of the surface water of eleven indiscriminate locations within the Pacific coil tells the best richness of plastics contaminant ever documented within the water. 10.5 years later, approximately in 2013, a study [87] according to which the central accumulation of microplastics within the Northeast Ocean to be 0.488 microplastics per money supply, that doubtless equates to 448,000 microplastics per $\mathrm{km}^{2}$. A study [88] of artificial debris within the Northwest Atlantic Ocean tells that sixty-nine of all items of plastic collected were within the size of 2-6mm, and half of 1 mile was smaller than $10 \mathrm{~mm}$ [62].

\section{Ecotoxicity of MPs}

The plastics present in the overall atmosphere has been increasing for decades [89, 90]. Microplastics are minutes of less than $\mathrm{mm}$ in size present in sediments and water and affect the environment. Since microplastics are the cause of harmful chemicals to marine living beings and nature, they are becoming a serious concern [91]. Production of secondary microplastics (MPs) involves fermentation that has a negative impact on our environment. They can be present from various sources in different forms such as fragments, fiber, foam, and so on [92]. For both public and government authorities presence of this new contaminant, microplastic, is a serious issue of concern [93]. Microplastics will cause many dangerous effects on living beings through processes like web and intake. Microplastics carry varied chemicals in water bodies. These toxicants might result in numerous health problems in human beings [94]. Researches are carried on an aquatic microorganism to study associated toxicants and alter their metabolic profiles to minimize the damage caused by plastic pollutant [95].

\subsection{Accumulation of MP in the living organism.}

The gathering and toxicity of microplastic contaminants in living beings act as a risk for human health. Human health is affected by microplastic and neoplastic present in the environment [96]. As organisms contact microplastic particles daily, it affects them dermally, orally, and in inhalation, resulting in risk factors [96, 97]. Metabolic transformation of PAHs will be weakened by the interaction of metabolic enzymes and microplastic, and increase their accumulation in organisms [98]. In fish, polysaccharide depletion and fat vacuolization can be caused by the accumulation of microplastics in the liver. Unleash of ecological contaminants adsorbate by them will manufacture a chain of pharmacological changes in the environment [99]. Real risk can not be reflected only by the individual toxicity of the pollutant. It is necessary to relate its contact and statistics with environmental pollution; therefore, it is mandatory to examine the relationship of micropollutants with the result of other pollutants present in the environment [100,101]. Current researches point out that microplastics can hinder the bioavailability of metals in the marine environment [102], PAHs [102-104], and PCBs [105]. Some process undergoes some physical-chemical changes [102, 103].

\subsection{Toxicity due to chemical and physical properties of MP.}

The fundamental information is provided by the physiochemical properties of microplastics [108]. In aquatic environments, bioavailability and toxicity are due to the inert nature of microplastics. Therefore, despite describing the properties related to physical science in detail, efforts are made to disclose the influence of microplastic concerning drinking, genetic responses of unusual type, and the thoughtful environmental implication [104]. The potential influence of microplastics is reflected majorly by the physical property and bioavailability of 
different species. Moreover, it depended on each property of the waste material and, therefore, the hunting [106]. Carnivores, main predators, are solely able to distinguish food from alternative substances supported restricted characteristics) area unit a lot of doubtless to intake microplastics with same options are available to their usual quarry [108]. The physical properties of microplastics affect the morphology and mobility in an aquatic environment. Bioavailability is littered with ever-changing distribution at intervals in the aquatic surroundings, presenting the same look to natural substances, associated inflicting totally unlike extents of mechanical misbalance to a microorganism. Some physical and chemical property affects negatively to the plastics contaminants [108]. The physical properties of microplastics and their impact is depicted in Figure 2.

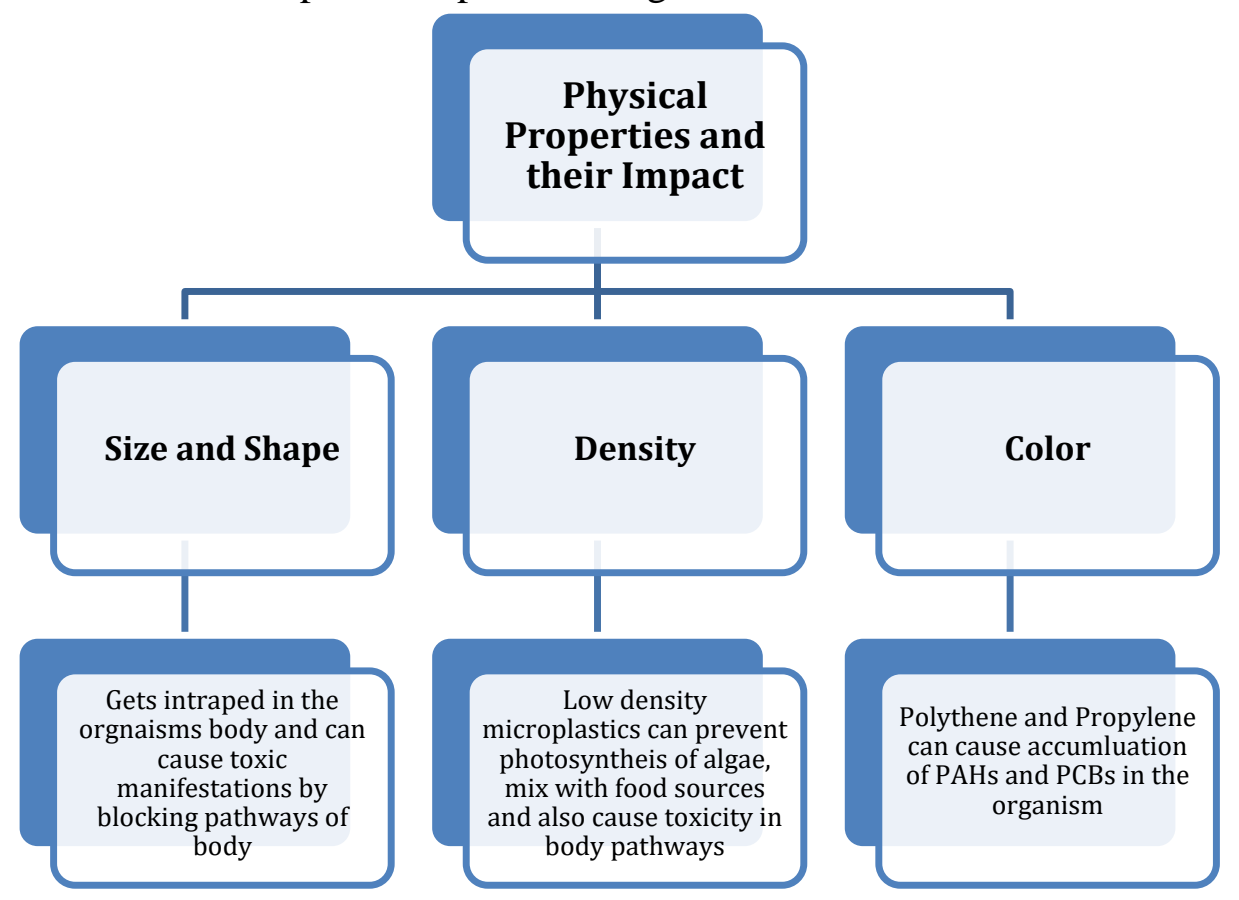

Figure 2. Impact of the physical properties of microplastics on living organisms.

Plastic composition and synthesis strategies decide the chemical nature of the microplastic, and it is uttered as different chemical features, like completely various practical teams, the polarity of surfaces, their stability, and creativity, that modifies the detection of the plastics contaminants with the probability to trickle particles or to gather ecological contaminants on the plane [108]. Persistence affinity for different chemicals is related to the directly affecting physical properties like ingestion, egesting, or any other physical injury and microplastic's morphological, chemical characteristics. The occurrence of microplastics changes the pattern of enhancement and release of additives; therefore, chemical properties are used to discuss the change in the behavior of microplastic $[107,108]$. The chemical properties of microplastics and their impact is depicted in Figure 3. 


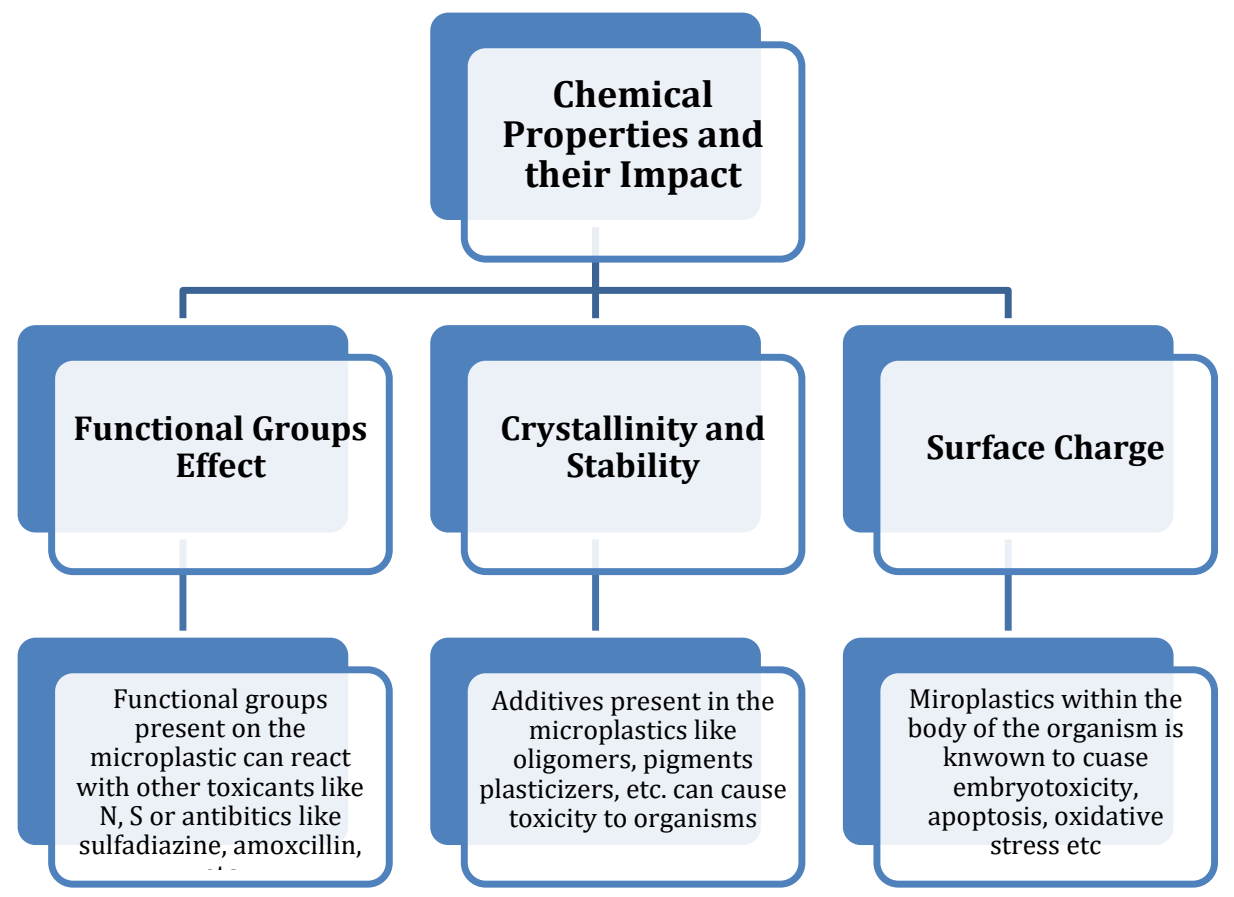

Figure 3. Impact of the chemical properties of microplastics on living organisms.

\subsection{Potential impact on aquatic life.}

The microplastics carry various toxins like additives from industrial production with the help of the natural action of the water [92]. Microplastic distribution is broadly distributed throughout the globe; freshwaters, oceans, and seas, together with the water column and sediments reaching so much because of the deep ocean [93]. Physical impacts primarily embrace web and body processes supported the studies on the microplastics in a sweater. In an exceedingly researches that have taken place [110], it has been determined that over two hundred naval species have been affected by the web and body process of artificial rubbish [110]. Though the limit to which physical effect affects organisms has remained undefined, the web result usually related to relatively giant flora and fauna is noticeable after comparing it with consumption [92]. Severe impacts on aquatic species are caused by entanglement. Some defenseless species are sea turtles, mammals, seabirds, and crustaceans [112]. When these animals drown in ghost nets, they will suffer from suffocation and starvation; once their predators seem, they are guaranteed to die [113]. Direct and indirect ingestion are the roots of microplastics entering the process. Accumulation effect is mainly seen in superior trophic levels like seabirds, seals, and sea lions; Fish are mainly intaken plastic contaminant by a predation action, and hence get affected [114-116]. The concentration issue of microplastics from water bodies to seals was rumored to be as high as one hundred sixty times [116-118]. The trap of microplastics typically happens to relatively massive marine organisms [119].On the opposite side, the activity of microplastics is found throughout the majority of the organic process levels, like fauna taxa [120], marine polychaete worm [118], mussel [125], oyster [121], fish [41], ocean turtles [122], dolphins [123], whales [124] and seabirds [126]. Key roles are played by biological and chemical factors. Toxicity can be observed after ingestion of microplastic. There are several pathways by which it can affect humans and other living organisms [92]. Several polymeric compounds carry out plastic production; some chemicals used during plastic productions are toxic, such as copper ions. More significantly, varied toxins in waters that square measure at the start combined onto microplastics could later be desorbed 
within human and animal bodies. Certain health effects are caused by polymeric compounds present in the plastic. For example, styrene (PS), proof against biodegradation, will accumulate within the abdomen of fish [127] and can translocate through blood circulation [128]. Bodily features, such as color, flame resistance, and hardness, are improved after adding additives during plastic production. The foremost ordinary preservative may be a softener to improve physical property or body [92]. As an example, vinyl resin (PVC) should have plasticizers like phthalates and biphenyl, so thermal and photo-degradation are reduced [130, 131]. The colorants and flame retardants are the properties that other additives include. Human bodies accumulate these chemicals by the process of bioaccumulation. Some of the well-known chemicals are endocrine-disrupting compounds [132]. In calculation, some molecules with serious metals like $\mathrm{Cr}, \mathrm{Cd}$, and $\mathrm{Pb}$ area units are typically utilized in the assembly of colorants, stabilizers, and plasticizers [131-134]. They will be discharged on or after synthetic trash keen on stream systems, and more goes into the organic phenomenon to cause bioaccumulation of poisons in microorganisms. PCBs area unit documented to be cancer, mutagenic, and/or agent [130]. The insecticide will result in adverse neurologic effects and immunological disorders [135].

\section{Detection and Removal of MP Contaminated Water}

Microplastics floating on the water bodies and buried in sediment are harmful and can result in environmental pollution [93]. Sample of contaminated microplastic is taken from different sources and then extracted and alienated in the laboratory environment. Therefore, isolation of the microplastics from the large samples for a satisfactory recovery becomes mandatory [93]. In alternative words, sample collection, extraction, examination of microplastics from the different sources becomes important [136, 137]. Sampling within the waters is often achieved by: surface trawls [138]. bongo nets [139]. Benthal trawls [139] vessels $[136,137]$ It has been proving that the isolation of microplastic from water is far easier than the isolation of bioremediation from sediments. Microplastic levels can be assets through the samples collected from the beaches, estuaries, and seafloor [138-141]. Stainless steel spoons or spatulas [140] and a box device [141] from land here are fewer chances for collection of soil or sediments, but on oceans, there are chances that sand, shells can come with microplastic [141-145]. There are two steps by which analysis of microplastics can be achieved first is purification, extraction, and the second is quantification, identification [92]. The microplastics should first be alienated from the primary medium to spice up or alter the subsequent quantification and/or identification $[92,93]$. Density separation is the foremost step in initial separation that includes integrating the sections with a known fluid-like saturated salt solution [93]. This method will modify particles with a low density to those of high density (high-density particle sink and low-density particle float). Thus recovery of contaminants becomes easier [92]. Traditionally microplastics were identified by the eye or microscopes. Properties like transparency, hardness, shape, and color of microplastics were examined [92]. Personal subjectivity maximizes the observational error linked with these methods. In the meantime, color and clarity can differ from environment to environment [93]. Microplastic pollution can also be identified by chromatographic analysis issues from mussels (gills and organic process glands; mainly digestive gland); extraction of samples was done in hydrated oxide and alcohol followed by microwave treatment [146-148]. High-performance liquid chromatography [HPLC] is done when methanolic solutions are refined [93]. Studies have proved that microplastic absorbs pyrene [149-152, 153]. Thermo analytical ways like shift gas 
chromatography and mass spectrometry, thermally treated samples underneath close circumstances, and therefore the discharged vapourish complex are unfree and later put into a gigahertz column [92]. This method is mainly used when the sample size is greater than 500 $\mathrm{mm}$ [92]. The section can be examined with the natural plastic additives a single time. A solvent is not used in this process; thus, background contamination is avoided; this method is highly reliable [92]. Polymer spectra knowledge library is accessible. Only 1 particle with a famous weight will be used per run. A pyrolysis database is available for some compounds like pyroxene [92]. Numerous analysis researches have delineated microplastics by examining the morphological features of victimization, their color, form [154-157] using optical microscopes, like stereomicroscope, and conjointly by visual examination [88]. There are some techniques by that surface morphology is often calculable [154-157]. The elemental composition of polymers and surface morphological characteristics are determined by ESEM-EDS and SEMEDS [90]. Fourier remodels infrared helps in identifying polymeric composition and identification of microplastic area [90]. Spectrometry, wherever the celebrated compound infrared spectra obtained from infrared spectrum libraries, might be harmonized with the infrared spectra [137, 143], which helped identify unevenly figured microplastics [90]. Molecules and atoms of the section have interacted with the irradiated laser light, resulting in the difference in the occurrence of the back-scattered beam compared to the irradiating laser $[92,93]$. Research tied Raman spectrometry (RS) methodology is suitable for particle size $>1$ millimeter. It is the sole methodology out there for particles falling within the vary of one to twenty millimeters. [92, 93] research connected RS permits the analysis for tiny particles between one to twenty millimeters with high abstraction resolution and relatively low sensitivity towards the water.

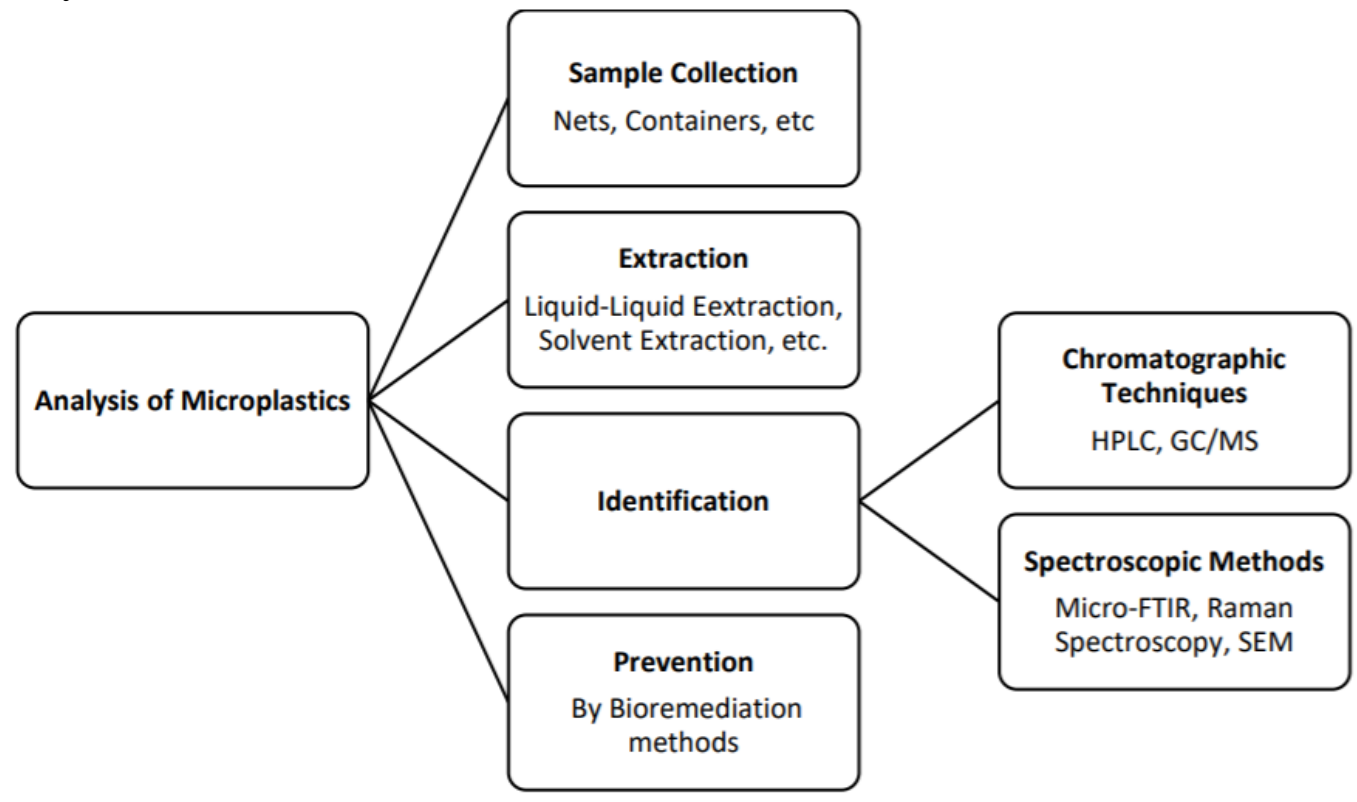

Figure 4. Laboratory procedural techniques for analysis of MPs present in water samples.

It is possible to analyze nontransparent and dark particles mistreatment RS methodology; the quick chemical mapping is often performed by the RS method, sanctioning quick and automatic information assortment /processing [158-162]. There area unit nice interferences of light from biological, organic, and inorganic impurities, hampering the identification of microplastics [92]. This methodology helps in creating the high-resolution image of the samples [163-166]. Since there is no elaborated identification data in the market, samples are necessary to be coated at a high vacuum [92,93]. Alternative strategies include 
tagging methodology surface of microplastic allows the hydrophobic dye to absorb on it and fluorescent it, after irradiation of blue lightweight [92]. Microplastics with a sample size below the microscale, i.e., primary microplastic are often unreal and counted. This methodology is easy and quick for microplastics which are low in value [92,93]. Particles having fluorescence are often counted and should be known. Alternative particles like organic junk may well be stained by the dye. This can result in an over-estimation of microplastics abundance [92]. The chemical properties of microplastics and their impact is depicted in Figure 4.

The natural process which is used to clean the environment using microbes (mostly fungi and bacteria) is termed bioremediation [160, 167-170]. The absence of microorganisms might have resulted in the accumulation of debris, and important nutrients that support life may be buried somewhere in the earth. Therefore the presence of microbes is bliss for nature [162, 171-173]. Bioremediation mainly focuses on cleaning and restoring the contaminated environment at comparatively less cost with no environmental degradation, as this process is carried out by eco-friendly microbes [163]. Nutrients that are needed for the continuation of life are targeted by these microorganisms [180]. All the carbon sources are targeted by them, whether plastic or any other material. The size of minute particles ranges from $1 \mathrm{~mm}$ to $5 \mathrm{~mm}$ $[165,166]$ and are produced from the chief resources, known as primary microplastics $[108$, 163]. Secondary microplastics are generated by various environmental factors and anthropogenic activities like degradation or littering of macroplastic [180]. City dust, marine coatings, tending product, plastic pellets, road markings, artificial textiles, and tires area unit referred to as the seven key sources of microplastics town mud, marine coatings, tending product, plastic pellets, road markings, artificial textiles, and tires area unit referred to as the seven key sources of microplastics [180]. According to global data, microplastics cause death to millions of marine animals (approx. 180 species) [165-167]. In the past, several techniques were used to manage the accumulation of microplastics. One of all the succeeding techniques that were used accurate tackle artificial desecrate is ablaze (but the burning of synthetic desecrate results in the manufacturing of different lethal gases within the surroundings), exercise (conversion of artificial in utilizable form, low price, and cheap goods reproduced), building (road and rail network were made with the help of plastic waste), manufacturing of gas (it remains completely hypothetical), and low landing (it took millions of years to degrade plastic) [170-173], all these methods have their merits and demerits [165]. Bioremediation is considered to be the most profitable and ecological method $[169,179]$. Two main categories of bioremediation are ex-situ bioremediation and in-situ bioremediation, depending on the site used to degrade the pollutant. In in-situ bioremediation, contaminates are despoiled at the contaminated location only, i.e., there is no waste transfer [174-178]. In ex-situ bioremediation, the contaminants are transferred from the contaminant site to another non-contaminated, safe site for degradation under controlled conditions like $\mathrm{pH}$ and temperature. (ex-situ bioremediation is preferred over in-situ bioremediation) composting is considered best among all the bioremediation techniques [180].

\section{Conclusions and Future Perspective}

Plastics are being produced at a large scale, and their usage has become a dependable part of our lives. Due to this large number of plastics present among us, it has caused severe environmental pollution. One of the major reasons for this type of pollution is because these plastics take thousands of years to decompose. Moreover, microplastics and their other forms are one of the major contributors to this havoc. It causes pollution and causes contamination of 
the environment, leading to an increased risk of ecotoxicity. These microplastics contaminate freshwater, marine water and cause harm to aquatic life. They are many developed method to detect and identify these threats to prevent further damage. This review discusses these critical areas related to microplastics to promote concise literature and promote future studies among researchers on this aspect of science. It is essential to recognize this emerging threat and effective strategies or methods need to be developed to prevent this damage. Awareness among individuals is needed to be done on a large scale to minimize/prevent plastic-related items. To minimize/prevent the use of plastics, a better and efficient replacement should be introduced in society. More future-oriented studies are needed to be devised to develop proper management and disposal strategies to control the damage from plastics. Bioremediation methods should be further improved and promoted in society to improve plastic management.

\section{Funding}

This review received no external funding.

\section{Acknowledgments}

The authors sincerely thank the reviewers for providing helpful comments on earlier drafts of the manuscript.

\section{Conflicts of Interest}

The authors declare no conflict of interest.

\section{References}

1. Coyle, R.; Hardiman, G.; O'Driscoll, K. Microplastics in the marine environment: A review of their sources, distribution processes, uptake and exchange in ecosystems. Case Stud. Chem. Environ. Eng. 2020, 2, 100010, https://doi.org/10.1016/j.cscee.2020.100010.

2. Rummel, C.D.; Löder, M.G.J.; Fricke, N.F.; Lang, T.; Griebeler, E.-M.; Janke, M., Gerdts, G. Plastic ingestion by pelagic and demersal fish from the North Sea and Baltic Sea. Mar. Pollut. Bull. 2016, 102, 134141, https://doi.org/10.1016/j.marpolbul.2015.11.043.

3. Koelmans, A. A.; Nor, N. H. M.; Hermsen, E.; Kooi, M.; Mintenig, S. M.; De France, J. Microplastics in freshwaters and drinking water: critical review and assessment of data quality. Water Res. 2019, 155, 410422, https://doi.org/10.1016/j.watres.2019.02.054.

4. GESAMP, S. fate and effects of microplastics in the marine environment: a global assessment, ed. PJ Kershaw (No. 90, p. 96). IMO/FAO/UNESCO-IOC/UNIDO/WMO/IAEA/UN/UNEP/UNDP Joint Group of Experts on the Scientific Aspects of Marine Environmental Protection), Rep. Stud.-GESAMP 2015.

5. Plastics Europe. Plastics - The Facts 2017. Plastics Europe, Brussels 2017; 44.

6. Bockhorn, H.; Hornung, A.; Hornung, U.; Schawaller, D. Kinetic study on the thermal degradation of polypropylene and polyethylene. J. Anal. Appl. Pyrolysis 1999, 48, 93-109, https://doi.org/10.1016/S01652370(98)00131-4.

7. Fries, E.; Dekiff, J.H.; Willmeyer, J.; Nuelle, M.-T.; Ebert, M.; Remy, D. Identification of polymer types and additives in marine microplastic particles using pyrolysis-GC/MS and scanning electron microscopy. Environ. Sci.: Processes Impacts 2013, 15, 1949-1956, https://doi.org/10.1039/C3EM00214D.

8. Andrady, A.L.; Neal, M.A. Applications and societal benefits of plastics. Philos. Trans.R. Soc. Lond. Ser. B Biol. Sci. 2009, 364, 1977-1984, https://doi.org/10.1098/rstb.2008.0304.

9. Zarfl, C.; Matthies, M. Are marine plastic particles transport vectors for organic pollutants to the Arctic?. Mar. Pollut. Bull. 2010, 60, 1810-1814, https://doi.org/10.1016/j.marpolbul.2010.05.026.

10. de Sá, L.C.; Luís, L.G.; Guilhermino, L. Effects of microplastics on juveniles of the common goby (Pomatoschistus microps): confusion with prey, reduction of the predatory performance and efficiency, and possible influence of developmental conditions. Environ. Pollut. 2015, 196, 359-362, 
https://doi.org/10.1016/j.envpol.2014.10.026

11. Rummel, C.D.; Löder, M.G.J.; Fricke, N.F.; Lang, T.; Griebeler, E.-M.; Janke, M., Gerdts, G. Plastic ingestion by pelagic and demersal fish from the North Sea and Baltic Sea. Mar. Pollut. Bull. 2016, 102, 134141, https://doi.org/10.1016/j.marpolbul.2015.11.043.

12. Herzke, D.; Anker-Nilssen, T.; Nøst, T.H.; Götsch, A.; Christensen-Dalsgaard, S.; Langset, M.; Fangel, K.; Koelmans, A.A. Negligible impact of ingested microplastics on tissue concentrations of persistent organic pollutants in northern fulmars off coastal Norway. Environ. Sci. Technol. 2016, 50, 1924-1933, https://doi.org/10.1021/acs.est.5b04663.

13. Fossi, M.C.; Panti, C.; Guerranti, C.; Coppola, D.; Giannetti, M.; Marsili, L.; Minutoli, R. Are baleen whales exposed to the threat of microplastics? A case study of the Mediterranean fin whale (Balaenoptera physalus). Mar. Pollut. Bull. 2012, 60, 2374-2379, https://doi.org/10.1016/j.marpolbul.2012.08.013.

14. Claessens, M.; Cauwenberghe, L.V.; Vandegehuchte, M.B.; Janssen, C.R. New techniques for the detection of microplastics in sediments and field collected organisms. Mar. Pollut. Bull. 2013, 70, 227-233, https://doi.org/10.1016/j.marpolbul.2013.03.009.

15. Eerkes-Medrano, D.; Thompson, R.C.; Aldridge, D.C. Microplastics in freshwater systems: a review of the emerging threats, identification of knowledge gaps and prioritisation of research needs. Water Res. 2015, 75, 63-82, https://doi.org/10.1016/j.watres.2015.02.012.

16. Wagner, M.; Scherer, C.; Alvarez-Munoz, D.; Breinholt, N.; Bourrain, X.; Buchinger, S.; Fries, E.; Grosbois, C.; Klasmeier, J.; Marti, T.; Rodriguez-Mozaz, S.; Urbatzka, R.; Vethaak, A.; Winther-Nielsen, M.; Reifferscheid, G. Microplastics in freshwater ecosystems: what we know and what we need to know. Environ. Sci. Eur. 2014, 26, 12, https://doi.org/10.1186/s12302-014-0012-7.

17. Phuong, N.N.; Zalouk-Vergnoux, A.; Poirier, L.; Kamari, A.; Châtel, A.; Mouneyrac, C.; Lagarde, F. Is there any consistency between the microplastics found in the field and those used in laboratory experiments? Environ. Pollut. 2016, 211, 111-123, https://doi.org/10.1016/j.envpol.2015.12.035.

18. Dris, R.; Gasperi, J.; Rocher, V.; Mohamed, S.; Renault, N.; Tassin, B. Microplastics contamination in a urban area: a case study in greater Paris. Environ. Chem. 2015, 12, 592-599, https://doi.org/10.1071/EN14167.

19. Oliveira, M.; Ribeiro, A.; Guilhermino, L. Effects of short-term exposure to microplastics and pyrene on Pomatoschistus microps (Teleostei, Gobiidae). Comp. Biochem. Physiol. A Mol. Integr. Physiol. 2012, 163, S20-S20, http://dx.doi.org/10.1016\%2Fj.cbpa.2012.05.063.

20. Oliveira, M.; Ribeiro, A.; Hylland, K.; Guilhermino, L. Single and combined effects of microplastics and pyrene on juveniles (0+ group) of the common goby Pomatoschistus microps (teleostei: gobiidae). Ecol. Indic. 2013, 34, 641-647, https://doi.org/10.1016/j.ecolind.2013.06.019.

21. Pochberger, M.; Kellenreitner, F.; Ahnelt, H.; Asmus, R.; Asmus, H. An abundant small sized fish as keystone species? The effect of Pomatoschistus microps on foodwebs and its trophic role in two intertidal benthic communities: a modeling approach. J. Sea Res. 2014, 86, 86-96, https://doi.org/10.1016/j.seares.2013.11.008.

22. de Sá, L.C.; Luís, L.G.; Guilhermino, L. Effects of microplastics on juveniles of the common goby (Pomatoschistus microps): confusion with prey, reduction of the predatory performance and efficiency, and possible influence of developmental conditions. Environ. Pollut. 2015, 196, 359-362, https://doi.org/10.1016/j.envpol.2014.10.026.

23. Desforges, J.P.W.; Galbraith, M.; Ross, P.S. Ingestion of microplastics by zooplankton in the Northeast Pacific Ocean. Arch. Environ. Contam. Toxicol. 2015, 69, 320-330, https://doi.org/10.1007/s00244-0150172-5.

24. Plastics Europe. Plastics - the Facts 2014/2015 An analysis of European plastics production, demand and waste data. Plastic Europe, Brussels, 2015.

25. Jambeck JR; Geyer R; Wilcox C; Siegler TR; Perryman M; Andrady A; Narayan R; Law K. L. Plastic waste inputs from land into the ocean. Science 2015, 347, 768-771, https://doi.org/10.1126/science.1260352.

26. Eriksen, M.; Lebreton, L. C. M.; Carson, H. S.; Thiel, M.; Moore, C. J.; Borerro, J. C.; Galgani, F.; Ryan, P.; Reisser, J. Plastic pollution in the world's oceans: more than 5 trillion plastics pieces weighing over 250,000 tons afloat at sea. PLoS One 2015, 9, e111913, https://doi.org/10.1371/journal.pone.0111913.

27. Woodall, L. C.; Sanchez-Vidal, A.; Canals, M.; Paterson, G. L. J.; Coppock, R.; Sleight, V.; Calafat, A.; Rogers, A. D.; Narayanaswamy, B. E.; Thompson, R. C. The deep sea is a major sink for microplastic debris. Royal Soc Open Sci 2014, 1, 140317, https://doi.org/10.1098/rsos.140317.

28. Browne, M. A.; Galloway, T. S.; Thompson, R. C. Spatial patterns of plastic debris along estuarine shorelines. 
Environ Sci Technol 2010, 44, 3404-3409, https://doi.org/10.1021/es903784e.

29. Song, Y. K.; Hong, S. H.; Jang, M.; Kang, J. H.; Kwon, O. Y.; Han, G. M.; Shim, W. J. Large accumulation of micro-sized synthetic polymer particles in the sea surface microlayer. Environ Sci Technol 2014, 48, 90149021, https://doi.org/10.1021/es501757s.

30. Obbard, R. W.; Sadri, S.; QiWong, Y.; Khitun, A. A.; Baker, I.; Thompson, R. C. Global warming releases microplastic legacy frozen in Arctic Sea ice. Earth's Future 2014, 2, 315-320, https://doi.org/10.1002/2014EF000240.

31. Law, K. L.; Thompson, R. C. Microplastics in the seas. Science 2014, 345, 144-145.

32. Wright, S. L.; Thompson, R. C.; Galloway, T. S. The physical impacts of microplastics on marine organisms: a review. Environ. Pollut. 2013, 178, 483-492, https://doi.org/10.1016/j.envpol.2013.02.031.

33. Gall, S. C.; Thompson, R. C. The impact of debris on marine life. Mar Pollut Bull 2015, 92, 170-179, https://doi.org/10.1016/j.marpolbul.2014.12.041.

34. Wright, S. L.; Rowe, D.; Thompson, R. C.; Galloway, T. S. Microplastic ingestion decreases energy reserves in marine worms. Curr Biol 2013, 23, 1031-1033, https://doi.org/10.1016/j.cub.2013.10.068.

35. Browne, M. A.; Niven, S. J.; Galloway, T. S.; Rowland, S. J.; Thompson, R. C. Microplastic moves pollutants and additives to worms, reducing functions linked to health and biodiversity. Current Biol 2013, 23, 23882392, https://doi.org/10.1016/j.cub.2013.10.012.

36. Rochman, C. M.; Hoh, E.; Kurobe, T.; Teh, S. J. Ingested plastic transfers hazardous chemicals to fish and induces hepatic stress. Sci Rep 2013, 3, 3263, https://doi.org/10.1038/srep03263.

37. Lithner, D.; Larsson, A.; Dave, G. Environmental and health hazard ranking and assessment of plastic polymers based on chemical composition. Sci Total Environ 2011, 409, 3309-3324, https://doi.org/10.1016/j.scitotenv.2011.04.038.

38. Lee, K. W.; Shim, W. J.; Kwon, O. Y.; Kang, J. H. Size-dependent effects of micro polystyrene particles in the marine copepod Tigriopus japonicus. Environ Sci Technol 2013, 47, 11278-11283, https://doi.org/10.1021/es401932b.

39. Seltenrich, N. New link in the marine food chain? Marine plastic pollution and seafood safety. Environ Health Persp 2015, 123, A34-A41, https://doi.org/10.1289/ehp.123-A34.

40. Talvitie, J.; Mikola, A.; Koistinen, A.; Setälä, O. Solutions to microplastic pollution-Removal of microplastics from wastewater effluent with advanced wastewater treatment technologies. Water Res. 2017, 123, 401-407, https://doi.org/10.1016/j.watres.2017.07.005.

41. GESAMP, S. fate and effects of microplastics in the marine environment: a global assessment, ed. PJ Kershaw (No. 90, p. 96). IMO/FAO/UNESCO-IOC/UNIDO/WMO/IAEA/UN/UNEP/UNDP Joint Group of Experts on the Scientific Aspects of Marine Environmental Protection), Rep. Stud.-GESAMP, 2015.

42. Microbead-Free Waters Act 2015. Available online: https://obamawhitehouse.archives.gov/thepressoffice/2015/12/28/statement-press-secretary-hr-1321-s-2425 (accessed on 15 May 2021).

43. Life p Mermaids. 2017. Available online: http://life-mermaids.eu/en/research/technologies/ (accessed on 10 April 2021).

44. Hernandez, E.; Nowack, B.; Mitrano, D. M. Polyester Textiles as a Source of Microplastics from Households: A Mechanistic Study to Understand Microfiber Release During Washing. Environ Sci Technol 2017, 51, 7036-7046, https://doi.org/10.1021/acs.est.7b01750.

45. Pirc, U.; Vidmar, M.; Mozer, A.; Kržan, A. Emissions of microplastic fibers from microfiber fleece during domestic washing. Environ Sci pollut Res 2016, 23, 22206-22211, https://doi.org/10.1007/s11356-016-77030 .

46. Browne, M. A. Sources and Pathways of Microplastics to Habitats. In Marine Anthropogenic Litter., Bergmann, M. Gutow, L., Klages, M. Eds.; Cham: Springer International Publishing 2015, 229-244.

47. Eerkes-Medrano, D.; Thompson, R. C.; Aldridge, D. C. Microplastics in freshwater systems: a review of the emerging threats, identification of knowledge gaps and prioritisation of research needs. Water Res 2015, 75, 63-82, https://doi.org/10.1016/j.watres.2015.02.012.

48. Horton, A. A.; Svendsen, C.; Williams, R. J.; Spurgeon, D. J.; Lahive, E. Large microplastic particles in sediments of tributaries of the River Thames, UK - Abundance, sources and methods for effective quantification. Mar. Pollut. Bull. 2017, 114, 218-226, https://doi.org/10.1016/j.marpolbul.2016.09.004.

49. Carr, S. A.; Liu, J.; Tesoro, A. G. Transport and fate of microplastic particles in wastewater treatment plants. Water Res 2016, 91, 174-182, https://doi.org/10.1016/j.watres.2016.01.002.

50. Murphy, F.; Russell, M.; Ewins, C.; Quinn, B. The uptake of macroplastic and microplastic by demersal and pelagic fish in the Northeast Atlantic around Scotland. Mar. Pollut. Bull. 2017, 122, 353-359, 
https://doi.org/10.1016/j.marpolbul.2017.06.073.

51. Li, C.; Busquets, R.; Campos, L. C. Assessment of microplastics in freshwater systems: A review. Sci. Total Environ. 2020, 707, 135578, https://doi.org/10.1016/j.scitotenv.2019.135578.

52. Browne, M.A.; Crump, P.; Niven, S. J.; Teuten, E.; Tonkin, A.; Galloway, T.; Thompson, R. Accumulation of microplastic on shorelines worldwide: sources and sinks Environ. Sci. Technol. 2011, 45, 9175-9179, https://doi.org/10.1021/es201811s.

53. Estahbanati, S. Fahrenfeld Influence of wastewater treatment plant discharges on microplastic concentrations in surface water. Chemosphere 2016, 162, 277-284, https://doi.org/10.1016/j.chemosphere.2016.07.083.

54. Ziajahromi, S.; Neale, P.; Leusch Wastewater treatment plant effluent as a source of microplastics: review of the fate, chemical interactions and potential risks to aquatic organisms. Water Sci. Technol. 2016, 74, 22532269, https://doi.org/10.2166/wst.2016.414.

55. Plastics Europe. Plastics the Facts 2015. An Analysis of European Latest Plastics Production, Demand and Waste Data; Plastics Europe: Association of Plastic Manufacturers: Brussels, Belgium 2016, 38.

56. Kleeberg, I.; Hetz, C.; Kroppenstedt, R. M.; Muller, R. J.; Deckwer, W. D. Biodegradation of aliphaticaromatic copolyesters by Thermomonospora fusca and other thermophilic compost isolates. Appl. Environ. Microbiol. 1998, 64, 1731-5.

57. Koelmans, A. A. ET.; C perspectives. Environ. Toxicol. Chem. 2014, 33, 5-10.

58. Jambeck, J. R.; Geyer, R.; Wilcox, C.; Siegler, T. R.; Perryman, M.; Andrady, A.; Narayan, R.; Law, K. L. Plastic waste inputs from land into the ocean. Science 2015, 347, 768-71, https://doi.org/10.1126/science.1260352.

59. Moreira, F. T.; Prantoni, A. L.; Martini, B.; De Abreu, M. A.; Stoiev, S. B.; Turra, A. Small-scale temporal and spatial variability in the abundance of plastic pellets on sandy beaches: methodological considerations for estimating the input of microplastics. Mar. Pollt. Bull. 2016, 102, 114-21, https://doi.org/10.1016/j.marpolbul.2015.11.051.

60. Neufeld, L.; Stassen, F.; Sheppard, R.; Gilman, T. In: The new plastics economy: rethinking the future of plastics. World Economic Forum, 2016.

61. Crawford, C. B.; Quinn, B. Microplastic pollutants. Elsevier Limited, 2016.

62. Horton, A. A.; Svendsen, C.; Williams, R. J.; Spurgeon., D. J.; Lahive, E. Large microplastic particles in sediments of tributaries of the River Thames, UK - Abundance, sources and methods for effective quantification. Mar Pollut Bull. 2017, 114, 218-26, https://doi.org/10.1016/j.marpolbul.2016.09.004.

63. Boucher, J; Friot, D. Primary microplastics in the oceans: a global evaluation of sources. Gland, Switzerland: IUCN, 2017.

64. Murphy, F.; Ewins, C.; Carbonnier, F.; Quinn, B. Wastewater Treatment Works (WwTW) as a Source of Microplastics in the Aquatic Environment. Environ Sci Technol. 2016, 50, 5800-8, https://doi.org/10.1021/acs.est.5b05416.

65. Browne, M. A.; Crump, P.; Niven, S. J.; Teuten, E.; Tonkin, A.; Galloway, T.; Thompson R. Accumulation of microplastic on shorelines woldwide: sources and sinks. Environ Sci Technol. 2011, 45, 9175-9, https://doi.org/10.1021/es201811s.

66. Vaughan, R.; Turner, S. D.; Rose, N. L. Microplastics in the sediments of a UK urban lake. Environ Pollut. 2017, 229, 10-8, https://doi.org/10.1016/j.envpol.2017.05.057.

67. Imhof, H. K.; Ivleva, N. P.; Schmid, J.; Niessner, R.; Laforsch, C. Contamination of beach sediments of a subalpine lake with microplastic particles. Curr Biol. 2013, 23, 867-8, https://doi.org/10.1016/j.cub.2013.09.001.

68. Free, C. M.; Jensen, O. P.; Mason, S. A.; Eriksen, M.; Williamson, N. J.; Boldgiv, B. High-levels of microplastic pollution in a large, remote, mountain lake. Mar Pollut Bull. 2014, 85, 156-63, https://doi.org/10.1016/j.marpolbul.2014.06.001.

69. PlasticsEurope. Plastics - the Facts 2016. An analysis of European plastics production, demand and waste data. 2016.

70. Lima, A. R. A.; Costa, M. F.; Barletta, M. Distribution patterns of microplastics within the plankton of a tropical estuary. Environ. Res. 2014, 132, 146-55, https://doi.org/10.1016/j.envres.2014.03.031.

71. Sadri, SS.; Thompson, RC. On the quantity and composition of floating plastic debris entering and leaving the Tamar Estuary, Southwest England. Marine Pollution Bulletin 2014, 81, 55-60, https://doi.org/10.1016/j.marpolbul.2014.02.020.

72. European Food Safety Authority (EFSA). Perfluoroalkylated substances in food: occurrence and dietary exposure. EFSA Journal 2012, 10, 2743-98, https://doi.org/10.2903/j.efsa.2012.2743. 
73. Witkowski, PJ.; Smith, JA.; Fusillo, TV.; Chiou, CT. A review of surface-water sediment fractions and their interactions with persistent manmade organic compounds. U.S. Geological Survey Circular 993USA: United States Government Printing Office; 1987.

74. Corcoran, PL.; Norris, T.; Ceccanese, T.; Walzak, MJ.; Helm, PA.; Marvin, CH. Hidden plastics of Lake Ontario, Canada and their potential preservation in the sediment record. Environmental Pollution 2015, 204, 17-25, https://doi.org/10.1016/j.envpol.2015.04.009.

75. Barnes, DK. Biodiversity: invasions by marine life on plastic debris. Nature 2002, 416, 808-9, https://doi.org/10.1038/416808a.

76. Horton, A.; Dixon, S. J. Microplastics: An introduction to environmental transport processes. Wiley Interdisciplinary Reviews: Water 2018, 5, 1268, https://doi.org/10.1002/wat2.1268.

77. Law KL, Thompson RC. Microplastics in the seas. Science 2014, 345, 144-5, https://doi.org/10.1126/science.1254065.

78. Zhang, Y.; Zhang, YB.; Feng, Y.; Yang, XJ. Reduce the plastic debris: a model research on the great Pacific ocean garbage patch. Adv Mat Res. 2010, 113, 59-63, https://doi.org/10.4028/www.scientific.net/AMR.113116.59 .

79. Wagner, M.; Lambert, S. Freshwater microplastics: emerging environmental contaminants?. Springer Nature. 2018.

80. Streb, J. Shaping the national system of inter-industry knowledge exchange vertical integration, licensing and repeated knowledge transfer in the German plastics industry. Research Policy 2003, 32, 1125-40, https://doi.org/10.1016/S0048-7333(02)00114-2.

81. Carpenter, EJ.; Smith, KL. Plastics on the Sargasso Sea surface. Science 1972, 175, 1240-1, https://doi.org/10.1126/science.175.4027.1240.

82. Colton, JB.; Knapp, FD.; Burns, BR. Plastic particles in surface waters of the Northwestern Atlantic. Science 1974, 185, 491-7.

83. Moore, CJ.; Moore, SL.; Leecaster, MK.; Weisberg, SB. A comparison of plastic and plankton in the North Pacific Central Gyre. Marine Pollution Bulletin 2001, 42, 1297-300, https://doi.org/10.1016/S0025326X(01)00114-X.

84. Bergami, E.; Bocci, E.; Vannuccini, ML.; Monopoli, M.; Salvati, A.; Dawson, KA.; Corsi, I. Nano-sized polystyrene affects feeding, behavior and physiology of brine shrimp Artemia franciscana larvae. Ecotoxicology and Environmental Safety 2016, 31, 18-25, https://doi.org/10.1016/j.ecoenv.2015.09.021.

85. Eriksen, M.; Lebreton, LCM.; Carson, HS.; Thiel, M.; Moore, CJ.; Borerro, JC.; Galgani, F.; Ryan, PG.; Reisser, J.; Plastic pollution in the world's oceans: more than 5 trillion plastic pieces weighing over 250,000 tons afloat at sea. PLoS One 2014, 9, 111913, https://doi.org/10.1371/journal.pone.0111913.

86. Habib, D.; Locke, DC.; Cannone, LJ.; Synthetic fibers as indicators of municipal sewage sludge, sludge products, and sewage treatment plant effluents. Water, Air, and Soil Pollution 1998, 103, 1-8, https://doi.org/10.1023/A:1004908110793.

87. Morét-Ferguson, S.; Law, KL.; Proskurowski, G.; Murphy, EK.; Peacock, EE.; Reddy, CM. The size, mass, and composition of plastic debris in the western North Atlantic Ocean. Marine Pollution Bulletin 2010, 60, 1873-8, https://doi.org/10.1016/j.marpolbul.2010.07.020.

88. Gall, S.; Thompson, R. The impact of debris on marine life. Marine Pollution Bulletin 2015, 92, 170-179, https://doi.org/10.1016/j.marpolbul.2014.12.041.

89. Hale, R. C. Analytical challenges associated with the determination of microplastics in the environment. 2017.

90. Pereao, O.; Opeolu, B.; Fatoki, O. Microplastics in aquatic environment: characterization, ecotoxicological effect, implications for ecosystems and developments in South Africa. Environmental Science and Pollution Research 2020, 27, 22271-22291, https://doi.org/10.1007/s11356-020-08688-2.

91. Rezania, S.; Park, J.; Din, M. F. M.; Taib, S. M.; Talaiekhozani, A.; Yadav, K. K.; Kamyab, H. Microplastics pollution in different aquatic environments and biota: A review of recent studies. Marine pollution bulletin 2018, 133, 191-208, https://doi.org/10.1016/j.marpolbul.2018.05.022.

92. Li, J.; Liu, H.; Chen, J. P. Microplastics in freshwater systems: A review on occurrence, environmental effects, and methods for microplastics detection. Water research 2018, 137, 362-374, https://doi.org/10.1016/j.watres.2017.12.056.

93. Yu, Y.; Zhou, D.; Li, Z.; Zhu, C. Advancement and challenges of microplastic pollution in the aquatic environment: a review. Water, air, \& soil pollution 2018, 229, 1-18, https://doi.org/10.1007/s11270-0183788-z. 
94. Galloway, T. S. Micro- and nano-plastics and human health. In: Bergmann M., Gutow L., Klages M. (eds) Marine anthropogenic litter, Springer 2015, 343-366.

95. Paul Pont, I.; Lacroix, C.; Fernández, C. G.; Hégaret, H.; Lambert, C.; Le, Goïc. N.; Guyomarch, J.; Frère, Laura, Cassone, Anne, Laure.; Sussarellu.; Rossana.; Fabioux.; Caroline.; Guyomarch.; Julien.; Albentosa.; Marina.; Huvet.; Arnaud.; Soudant, Philippe. Exposure of marine mussels Mytilus spp. to polystyrene microplastics: toxicity and influence on fluoranthene bioaccumulation. Environmental Pollution 2016, 216, 724-737, https://doi.org/10.1016/j.envpol.2016.06.039.

96. Rochman, C. M.; Hoh, E.; Hentschel, B. T.; Kaye, S. Long -term field measurement of sorption of organic contaminants to five types of plastic pellets: implications for plastic marine debris. Environmental Science and Technology 2013, 47, 1646 -1654, https://doi.org/10.1021/es303700s.

97. Li, C.; Busquets, R.; Campos, L. C. Assessment of microplastics in freshwater systems: A review. Science of the Total Environment 2020, 707, 135578, https://doi.org/10.1016/j.scitotenv.2019.135578.

98. Brennecke, D.; Duarte, B.; Paiva, F.; Caçador, I.; and Canning-Clode, J. Microplastics as vector for heavy metal contamination from the marine environment. Estuarine, Coastal and Shelf Science 2016, 178, 189 195, https://doi.org/10.1016/j.ecss.2015.12.003.

99. Karami, A.; Romano, N.; Galloway, T.; Hamzah, H. Virgin microplastics cause toxicity and modulate the impacts of phenanthrene on biomarker responses in African (Clarias gariepinus). Environmental research 2016, 151, 58 -70, https://doi.org/10.1016/j.envres.2016.07.024.

100. Oliveira, M.; Ribeiro, A.; Hylland, K.; and Guilhermino, L. Single and combined effects of microplastics and pyrene on juveniles (0+ group) of the common goby Pomatoschistus microps (Teleostei, Gobiidae). Ecological Indicators 2013, 34, 641 -647, https://doi.org/10.1016/j.ecolind.2013.06.019.

101.Sleight, V. A.; Bakir, A.; Thompson, R. C.; and Henry, T. B. Assessment of microplastic -sorbed contaminant bioavailability through analysis of biomarker gene expression in larval zebrafish. Marine Pollution Bulletin 2017, 116, 291 - 297, https://doi.org/10.1016/j.marpolbul.2016.12.055.

102. Setala, O.; Norkko, J.; Lehtiniemi, M. Feeding type affects microplastic ingestion in a coastal invertebrate community. Mar. Pollut. Bull. 2016, 102 1, 95e101, https://doi.org/10.1016/j.marpolbul.2015.11.053.

103.Peters, C. A.; Thomas, P. A.; Rieper, K. B.; Bratton, S. P. Foraging preferences influence microplastic ingestion by six marine fish species from the Texas Gulf Coast. Marine pollution bulletin. 2017, 124, 1, 8288, https://doi.org/10.1016/j.marpolbul.2017.06.080.

104.Ma, H.; Pu, S.; Liu, S.; Bai, Y.; Mandal, S.; Xing, B. Microplastics in aquatic environments: Toxicity to trigger ecological consequences. Environmental Pollution $\quad$ 2020, 261, 114089, https://doi.org/10.1016/j.envpol.2020.114089.

105.Laist, D.W. Impacts of marine debris: entanglement of marine life in marine debris including a comprehensive list of species with entanglement and ingestion records. Mar. Debris Sources Impacts Solut 1997, 152, 6, 99140, https://doi.org/10.1007/978-1-4613-8486-1_10.

106. Allsopp, M.; Walters, A.; Santillo, D.; Johnston, P. Plastic debris in the world's oceans 2016.

107.Gilardi, K. V.; Carlson-Bremer, D.; June, J. A.; Antonelis, K.; Broadhurst, G.; \& Cowan, T. Marine species mortality in derelict fishing nets in Puget Sound, WA and the cost/benefits of derelict net removal. Marine pollution bulletin 2010, 603, 376-382, https://doi.org/10.1016/j.marpolbul.2009.10.016.

108.Derraik, J.G.B. The pollution of the marine environment by plastic debris: a review. Mar. Pollut. Bull. 2002, 9, 842-852, https://doi.org/10.1016/S0025-326X(02)00220-5.

109.Romeo, T.; Pietro, B.; Pedà, C.; Consoli, P.; Andaloro, F.; Fossi, M. C. First evidence of presence of plastic debris in stomach of large pelagic fish in the Mediterranean Sea. Marine pollution bulletin 2015, 95, 358361, https://doi.org/10.1016/j.marpolbul.2015.04.048.

110.McMahon, C. R.; Holley, D.; Robinson, S. The diet of itinerant male Hooker's sea lions, Phocarctos hookeri, at sub-Antarctic Macquarie Island. Wildlife Research. 1999, 26, 839-846, https://doi.org/10.1071/WR98079.

111.Eriksson, C.; Burton, H. Origins and biological accumulation of small plastic particles in fur seals from Macquarie Island. AMBIO: A Journal of the Human Environment. 2013, 32, 380-384, https://doi.org/10.1579/0044-7447-32.6.380.

112.Eerkes-Medrano, D.; Thompson, R. C.; Aldridge, D. C. Microplastics in freshwater systems: a review of the emerging threats, identification of knowledge gaps and prioritisation of research needs. Water research 2015 , 75, 63-82, https://doi.org/10.1016/j.watres.2015.02.012.

113.Wright, S. L.; Thompson, R. C.; Galloway, T. S. The physical impacts of microplastics on marine organisms: a review. Environmental pollution 2013, 178, 483-492, https://doi.org/10.1016/j.envpol.2013.02.031. 
114. Sankhla, Mahipal Singh.; Kumari, Mayuri.; Nandan, Manisha.; Kumar, Rajeev.; Agrawal, Prashant. Heavy Metals Contamination in Water and Their Hazardous Effect on Human Health-A Review. International Journal of Current Microbiology and Applied Sciences 2016, $5 \quad$ (10), 759766, http://dx.doi.org/10.2139/ssrn.3428216.

115.Cole, M.; Webb, H.; Lindeque, P.K.; Fileman, E.S.; Halsband, C.; Galloway, T.S. Isolation of microplastics in biota-rich seawater samples and marine organisms. Sci. Rep. 2014, 4, 4528.

116.Sussarellu, R.; Suquet, M.; Thomas, Y.; Lambert, C.; Fabioux, C.; Pernet, M.E.J.; Le Goïc, N.; Quillien, V.; Mingant, C.; Epelboin, Y.; Corporeau, C.; Guyomarch, J.; Robbens, J.; Paul-Pont, I.; Soudant, P.; Huvet, A. Oyster reproduction is affected by exposure to polystyrene microplastics. Proc. Natl. Acad. Sci. U. S. A. 2016, 113, 2430e2435, https://doi.org/10.1073/pnas.1519019113.

117.Bugoni, L.; Krause, L.g.; Virgínia Petry, M. Marine debris and human impacts on sea turtles in Southern Brazil. Mar. Pollut. Bull. 2001, 42, 1330-1334, https://doi.org/10.1016/S0025-326X(01)00147-3.

118.Denuncio, P.; Bastida, R.; Dassis, M.; Giardino, G.; Gerpe, M.; Rodríguez, D. Plastic ingestion in Franciscana dolphins, Pontoporia blainvillei (Gervais and d'Orbigny, 1844), from Argentina. Mar. Pollut. Bull. 2011, 62, 1836-1841, https://doi.org/10.1016/j.marpolbul.2011.05.003.

119. Walker, W. A.; Coe, J. M. Survey of marine debris ingestion by odontocete cetaceans. In Proceedings of the second international conference on marine debris. 1989, 154, 2-7.

120. Von Moos, N.; Burkhardt-Holm, P.; Köhler, A. Uptake and effects of microplastics on cells and tissue of the blue mussel Mytilus edulis L. after an experimental exposure. Environmental science \& technology. 2012, 46, 11327-11335, https://doi.org/10.1021/es302332w.

121.Derraik, J.G.B. The pollution of the marine environment by plastic debris: a review. Mar. Pollut. Bull. 2002 , 44, 842-852, https://doi.org/10.1016/S0025-326X(02)00220-5.

122.Carpenter, E.J.; Anderson, S.J.; Harvey, G.R.; Miklas, H.P.; Peck, B.B. Polystyrene spherules in coastal waters. Science 1972, 178, 749-750, https://doi.org/ 10.1126/science.178.4062.749.

123.Chen, J.; Tan, M.; Nemmar, A.; Song, W.; Dong, M.; Zhang, G.; Li, Y. Quantification of extrapulmonary translocation of intratracheal-instilled particles in vivo in rats: effect of lipopolysaccharide. Toxicology 2006, 222, 195-201, https://doi.org/10.1016/j.tox.2006.02.016.

124.Sussarellu, R., Suquet, M.; Thomas, Y.; Lambert, C.; Fabioux, C.; Pernet, M. E. J.; Huvet, A. Oyster reproduction is affected by exposure to polystyrene microplastics. Proceedings of the National Academy of Sciences 2016, 113, 2430-2435, https://doi.org/10.1073/pnas.1519019113.

125.Hammer, J., Kraak, M. H., Parsons, J. R. Plastics in the marine environment: the dark side of a modern gift. Reviews of environmental contamination and toxicology 2012, 1-44, https://doi.org/10.1007/978-14614-3414-6_1.

126.Tagg, A. S.; Sapp, M.; Harrison, J. P.; \& Ojeda, J. J. Identification and quantification of microplastics in wastewater using focal plane array-based reflectance micro-FT-IR imaging. Analytical chemistry 2015, 87, 6032-6040, https://doi.org/10.1007/978-1-4614-3414-6_1.

127.Ernst, T.; Popp, R.; van Eldik, R. Quantification of heavy metals for the recycling of waste plastics from electrotechnical applications. Talanta 2000, 53, 347-357, https://doi.org/10.1016/S0039-9140(00)00491-4.

128. Murphy, J. (Ed.). Additives for plastics handbook. 2001, Elsevier.

129. Mansouri, A.; Cregut, M.; Abbes, C.; Durand, M. J.; Landoulsi, A.; Thouand, G. The environmental issues of DDT pollution and bioremediation: a multidisciplinary review. Applied biochemistry and biotechnology 2017, 181, 309-339, https://doi.org/10.1007/s12010-016-2214-5.

130.Rocha-Santos, T.; Duarte, A. C. A critical overview of the analytical approaches to the occurrence, the fate and the behavior of microplastics in the environment. Trends in Analytical Chemistry 2015, 65, 47-53, https://doi.org/10.1016/j.trac.2014.10.011.

131.Mbachu, O.; Jenkins, G.; Kaparaju, P.; Pratt, C. The rise of artificial soil carbon inputs: Reviewing microplastic pollution effects in the soil environment. Science of The Total Environment 2021, 19, 146569, https://doi.org/10.1016/j.scitotenv.2021.146569.

132.De Carvalho, AR.; Garcia, F.; Riem-Galliano, L.; Tudesque, L.; Albignac, M.; Ter Halle , A.; Cucherousset J. Urbanization and hydrological conditions drive the spatial and temporal variability of microplastic pollution in the Garonne River. Science of the Total Environment 2021, 15, 144479, https://doi.org/10.1016/j.scitotenv.2020.144479.

133.Dubaish, F.; Liebezeit, G. Suspended microplastics and black carbon particles in the Jade system, southern North Sea. Water, Air, and Soil Pollution 2015, 224, 1352, https://doi.org/10.1007/s11270-012-1352-9. 
134.Claessens, M.; De Meester, S.; Van Landuyt, L.; De Clerck, K.; Janssen, C. R. Occurrence and distribution of microplastics in marine sediments along the Belgian coast. Marine Pollution Bulletin 2011, 62, 21992204, https://doi.org/10.1016/j.marpolbul.2011.06.030.

135.Garcia, F.; de Carvalho, AR.; Riem-Galliano, L.; Tudesque, L.; Albignac, M.; Ter Halle, A.; Cucherousset, J. Stable isotope insights into microplastic contamination within freshwater food webs. Environmental science \& technology 2021, 7, 1024-35, https://doi.org/10.1021/acs.est.0c06221.

136. Cole, M.; Lindeque, P.; Halsband, C.; Galloway, T. S. Microplastics as contaminants in the marine environment: a review. Marine Pollution Bulletin 2011, 62, 2588-2597, https://doi.org/10.1016/j.marpolbul.2011.09.025.

137.Zhang, D.; Fraser, MA.; Huang, W.; Ge, C.; Wang, Y.; Zhang, C.; Guo P. Microplastic pollution in water, sediment, and specific tissues of crayfish (Procambarus clarkii) within two different breeding modes in Jianli, $\begin{array}{llllll}\text { Hubei province, } & \text { China. } & \text { Environmental } & \text { Pollution } & \mathbf{2 0 2 1} & \text { 272, }\end{array}$ https://doi.org/10.1016/j.envpol.2020.115939.

138.Harrison, J.; Ojeda, J.; Romero-González, M. The applicability of reflectance micro-Fourier-transform infrared spectroscopy for the detection of synthetic microplastics in marine sediments. Science of the Total Environment 2011, 416, 455-463, https://doi.org/10.1016/j.scitotenv.2011.11.078.

139. Sankhla, M. S.; Kumar, R.; Shefali. New and Advanced Technologies in Aquaculture to Support Environmentally Sustainable Development. Microbial Biotechnology: Basic Research and Applications, Springer. 2020. 1, 249-263, https://doi.org/10.1007/978-981-15-2817-0_11.

140.Vianello, A.; Boldrin, A.; Guerriero, P.; Moschino, V.; Rella, R.; Sturaro, A.; Da Ros, L. Microplastic particles in sediments of lagoon of Venice, Italy: first observations on occurrence, spatial patterns and identification. Estuarine, Coastal and Shelf Science. 2013, 130, 54-61, https://doi.org/10.1016/j.ecss.2013.03.022.

141. Van Cauwenberghe, L.; Claessens, M.; Vandegehuchte, M. B.; Mees, J.; Janssen, C. R. Assessment of marine debris on the Belgian Continental Shelf. Marine Pollution Bulletin 2013 73, 161-169, https://doi.org/10.1016/j.marpolbul.2013.05.026.

142.Mohan, H.; Rajput, SS.; Jadhav, EB.; Sankhla, MS.; Sonone, SS.; Jadhav, S.; Kumar, R. Ecotoxicity, Occurrence, and Removal of Pharmaceuticals and Illicit Drugs from Aquatic Systems. Biointerface Research in Applied Chemistry 2021, 11, 12530-46, https://doi.org/10.33263/BRIAC115.1253012546.

143. Van Cauwenberghe, L., Vanreusel, A., Mees, J., Janssen, C. R. Microplastic pollution in deep-sea sediments. Environmental Pollution 2013, 182, 495-499, https://doi.org/10.1016/j.envpol.2013.08.013.

144. Kiendrebeogo M, Estahbanati MK, Mostafazadeh AK, Drogui P, Tyagi RD. Treatment of microplastics in water by anodic oxidation: A case study for polystyrene. Environmental Pollution 2021, 15, 116-168, https://doi.org/10.1016/j.envpol.2020.116168.

145.Benedetti, M.; Gorbi, S.; Fattorini, D.; D'Errico, G.; Piva, F.; Pacitti, D.; Regoli, F. Environmental hazards from natural hydrocarbons seepage: integrated classification of risk from sediment chemistry, bioavailability and biomarkers responses in sentinel species. Environmental Pollution 2014, 185, 116-126, https://doi.org/10.1016/j.envpol.2013.10.023.

146.Rebelein, A.; Int-Veen, I.; Kammann, U.; Scharsack, JP. Microplastic fibers-underestimated threat to aquatic organisms?. Science of The Total Environment 2021, 1, 146045, https://doi.org/10.1016/j.scitotenv.2021.146045.

147.Avio, C. G.; Gorbi, S.; Milan, M.; Benedetti, M.; Fattorini, D.; d'Errico, G.; Pauletto, M.; Bargelloni, L.; Regoli, F. Pollutants bioavailability and toxicological risk from microplastics to marine mussels. Environmental Pollution 2015, 198, 211-222, https://doi.org/10.1016/j.envpol.2014.12.021.

148. Makhdoumi, P.; Amin, AA.; Karimi, H.; Pirsaheb, M.; Kim, H.; Hossini, H. Occurrence of microplastic particles in the most popular Iranian bottled mineral water brands and an assessment of human exposure. Journal of Water Process Engineering 2021, 1, 101708, https://doi.org/10.1016/j.jwpe.2020.101708.

149.Fries, E.; Dekiff, JH.; Willmeyer, J.; Nuelle, MT.; Ebert, M.; Remy, D. Identification of polymer types and additives in marine microplastic particles using pyrolysis-GC/MS and scanning electron microscopy. Environ Sci Process Impacts 2015, 15, 1949-1956, https://doi.org/10.1039/C3EM00214D.

150.Xia, B.; Sui, Q.; Sun, X.; Zhu, L.; Wang, R.; Cai, M.; Chen, B.; Qu, K. Microplastic pollution in surface seawater of Sanggou Bay, China: Occurrence, source and inventory. Marine Pollution Bulletin 2021, 1, 111899, https://doi.org/10.1016/j.marpolbul.2020.111899.

151.Eriksen, M.; Mason, S.; Wilson. S. Microplastic pollution in the surface waters of the Laurentian Great Lakes. Mar Pollut Bull. 2013, 77, 177-182, https://doi.org/10.1016/j.marpolbul.2013.10.007. 
152.Pastorino, P.; Pizzul, E.; Bertoli, M.; Anselmi, S.; Kušće, M.; Menconi, V.; Prearo, M.; Renzi M. First insights into plastic and microplastic occurrence in biotic and abiotic compartments, and snow from a high-mountain lake (Carnic Alps). Chemosphere 2021, 265, 129121, https://doi.org/10.1016/j.chemosphere.2020.129121.

153.Napper, IE.; Baroth, A.; Barrett, AC.; Bhola, S.; Chowdhury, GW.; Davies, BF.; Duncan, EM.; Kumar, S.; Nelms, SE.; Niloy, MN.; Nishat, B. The abundance and characteristics of microplastics in surface water in the transboundary Ganges River. Environmental Pollution 2021, 274, 116348, https://doi.org/10.1016/j.envpol.2020.116348.

154.Desforges, J-PW.; Galbraith, M.; Dangerfield, N.; Ross, PS. Widespread distribution of microplastics in subsurface seawater in the NE Pacific Ocean. Mar Pollut Bull. 2014, 79, 94-99, https://doi.org/10.1016/j.marpolbul.2013.12.035.

155.Ziajahro mi S, Neale PA, Silveira IT, Chua A, Leusch FD. An audit of microplastic abundance throughout three Australian wastewater treatment plants. Chemosphere 2021, 263, 128294, https://doi.org/10.1016/j.chemosphere.2020.128294.

156. Reisser, J.; Shaw, J.; Wilcox, C. Marine plastic pollution in waters around Australia: characteristics, concentrations, and pathways. PLoS One 2013, 8, e80466, https://doi.org/10.1371/journal.pone.0080466.

157.Zhang K, Hamidian AH, Tubić A, Zhang Y, Fang JK, Wu C, Lam PK. Understanding plastic degradation and microplastic formation in the environment: A review. Environmental Pollution 2021, 23, 116554, https://doi.org/10.1016/j.envpol.2021.116554.

158.Korda, A.; Santas, P.; Tenente, A.; Santas, R. Petroleum hydrocarbon bioremediation: sampling and analytical techniques, in situ treatments and commercial microorganisms currently used. Appl Microbiol Biotechno. 1997, 48, 677-686, https://doi.org/10.1007/s002530051115.

159.Pan, Z.; Liu, Q.; Jiang, R.; Li, W.; Sun, X.; Lin, H.; Jiang, S.; Huang, H. Microplastic pollution and ecological risk assessment in an estuarine environment: The Dongshan Bay of China. Chemosphere 2021, 262, 127876, https://doi.org/10.1016/j.chemosphere.2020.127876.

160. National Research C. In situ bioremediation: when does it work? National Academies Press, Atlanta. 1993.

161. Azubuike, CC.; Chikere, CB.; Okpokwasili, GC. Bioremediation techniques-classification based on site of application: principles, advantages, limitations and prospects. World J Microbiol Biotechnol. 2016, 32, 180, https://doi.org/10.1007/s11274-016-2137-X

162.Sathicq, MB.; Sabatino, R.; Corno, G.; Di Cesare, A. Are microplastic particles a hotspot for the spread and the persistence of antibiotic resistance in aquatic systems?. Environmental Pollution 2021, 10, 116896, https://doi.org/10.1016/j.envpol.2021.116896.

163.Cole, M.; Lindeque, P.; Fileman, E.; Halsband, C.; Goodhead, R.; Moger, J.; Galloway, TS. Microplastic ingestion by zooplankton. Environ Sci Technol 2013, 47, 6646-6655, https://doi.org/10.1021/es400663f.

164. Boucher, J.; Friot, D. Primary microplastics in the oceans: a global evaluation of sources. International Union for Conservation of Nature and Natural Resources (IUCN), Gland. 2017.

165. Alfaro-Núñez, A.; Astorga, D.; Cáceres-Farías, L.; Bastidas, L.; Villegas, CS.; Macay, K.; Christensen, JH. Microplastic pollution in seawater and marine organisms across the Tropical Eastern Pacific and Galápagos. Scientific reports 2021, 11, 1-8, https://doi.org/10.1038/s41598-021-85939-3.

166. Wang, J.; Tan, Z.; Peng, J.; Qiu, Q.; Li, M. The behaviors of microplastics in the marine environment. Mar Environ Res. 2016, 113, 7-17, https://doi.org/10.1016/j.marenvres.2015.10.014.

167. Hartman, WJ Jr. An evaluation of land treatment of municipal wastewater and physical siting of facility installations. Office of the Chief of Engineers (Army), Washington, DC. 1975.

168. Cooper, DA.; \& Corcoran, PL. Effects of mechanical and chemical processes on the degradation of plastic beach debris on the island of Kauai, Hawaii. Mar Pollut Bull. 2010, 60, 650-654, https://doi.org/10.1016/j.marpolbul.2009.12.026.

169.Sarker, M. Converting waste plastic to hydrocarbon fuel materials. Energy Eng. 2011, 108, 35-43, https://doi.org/10.1080/01998595.2011.10389018.

170.Golwala, H.; Zhang, X.; Iskander, SM.; Smith, AL. Solid waste: An overlooked source of microplastics to the environment. Science of the Total Environment 2021, 9, 144581, https://doi.org/10.1016/j.scitotenv.2020.144581.

171. Shahnawaz, M. 2016. Studies on collection, isolation, screening and molecular characterization of polythene degrading bacteria from the rhizosphere of Avicennia marina (Forsk.) Vierh. collected from West Coast of India. Ph. D. Thesis. Department of Botany, Savitribai Phule Pune University, Pune, Maharashtra, India, https://doi.org/10.1007/s11356-016-6542-3. 
172.Shah, AA.; Hasan, F.; Hameed, A.; Ahmed, S. Biological degradation of plastics: a comprehensive review. Biotechnol Adv. 2008, 26, 246-265, https://doi.org/10.1016/j.biotechadv.2007.12.005.

173. Sangale, MK.; Shahnawaz, M.; Ade, AB. A review on biodegradation of polythene: the microbial approach. J Bioremed Biodeg. 2012, 3, 1-9, http://dx.doi.org/10.4172/2155-6199.1000164.

174. Shahnawaz, M.; Sangale, M. K.; Ade, A. B. Bioremediation Technology for Plastic Waste. 2019.

175.Kawasaki, E. S.; \& Player, A. Nanotechnology, nanomedicine, and the development of new, effective therapies for cancer. Nanomedicine: Nanotechnology, Biology and Medicine. 2015, 2, 101-109, https://doi.org/10.1016/j.nano.2005.03.002.

176.González-Pleiter, M.; Pedrouzo-Rodríguez, A.; Verdú, I.; Leganés, F.; Marco, E.; Rosal, R.; Fernández-Piñas, F. Microplastics as vectors of the antibiotics azithromycin and clarithromycin: Effects towards freshwater microalgae. Chemosphere 2021, 268, 128824, https://doi.org/10.1016/j.chemosphere.2020.128824.

177.Jiang, M.; Qi, Y.; Liu, H.; \& Chen, Y. The role of nanomaterials and nanotechnologies in wastewater treatment: a bibliometric analysis. Nanoscale research letters 2018, 13, 1-13.

178. Kuswandi, B. Nanobiosensors for detection of micropollutants. Environmental nanotechnology Springer. 2018, 125-158, https://doi.org/10.1007/978-3-030-36260-7_3.

179. McNeil, S. E. Nanotechnology for the biologist. Journal of leukocyte biology 2005, 78, 585-594, https://doi.org/10.1189/jlb.0205074.

180.Nguyen, B.; Claveau-Mallet, D.; Hernandez, L. M.; Xu, E. G.; Farner, J. M.; Tufenkji, N. Separation and analysis of microplastics and nanoplastics in complex environmental samples. Accounts of chemical research 2019, 52, 858-866, https://doi.org/10.1021/acs.accounts.8b00602. 